Vol 1. No. 3, Juli 2021 P-ISSN : 2774-8030, e-ISSN : 2774-8030

\title{
EFEKTIVITAS PENGGUNAAN GOOGLE FORM SELAMA BELAJAR DARI RUMAH DALAM PELAKSANAAN LAYANAN BIMBINGAN KLASIKAL
}

\author{
AGUS SUPRIADI \\ SMP Negeri 8 Pamekasan \\ e-mail: abahagus65@gmail.com
}

\begin{abstract}
ABSTRAK
Tujuan dari penelitian ini adalah ingin memaparkan dari efektivitas pelaksanaan kegiatan layanan bimbingan klasikal selama belajar dari rumah pada masa pandemi COVID 19 dengan menggunakan media/platform google form di SMP Negeri 8 Pamekasan Tahun Pelajaran 2020/2021. Penelitian ini menggunakan penelitian lapangan dengan pendekatan kualitatif deskriptif pada peserta didik kelas kelas IX SMP Negeri 8 Pamekasan. Hasil dari peneltian ini menunjukkan bahwa pelaksanaan kegiatan layanan bimbingan klasikal secara daring melalui media google form menunjukkan hasil yang efektif. Hal ini ditunjukkan dari hasil penelitian yakni perasaan menyenangkan $77 \%$, topik yang dibahas dianggap penting $93 \%$, cara guru BK dalam menyampaikan materi mudah dipahami $85 \%$, dan kegiatan menarik untuk diikuti $83 \%$.
\end{abstract}

Kata Kunci : Efektivitas, Google Form, Bimbingan Klasikal

\section{PENDAHULUAN}

Efektivitas secara umum adalah keadaan yang menunjukkan tingkat keberhasilan atau pencapaian suatu tujuan yang diukur dengan kualitas, kuantitas dan waktu sesuai dengan yang telah direncanakan sebelumnya. Menurut Supardi (2013) pelaksanaan layanan BK efektif adalah kombinasi yang tersusun meliputi manusiawi, material, fasilitas, perlengkapan dan prosedur diarahkan untuk mengubah perilaku peserta didik kearah yang positif dan lebih baik sesuai dengan potensi dan perbedaan yang dimiliki peserta didik untuk mencapai tujuan pelaksanaan layanan BK yang telah ditetapkan.

Salah satu bentuk pelaksanaan layanan BK alternative yang dapat dilaksanakan selama masa pandemi COVID-19 adalah pelaksanaan layanan BK secara online/daring atau lebih dikenal dengan BDR (Belajar Dari Rumah). Pelaksanaan layanan BK online/daring merupakan pelaksanaan layanan BK yang menggunakan jaringan internet dengan aksesibilitas, konektivitas, fleksibilitas dan kemampuan untuk memunculkan berbagai jenis interaksi pelaksanaan layanan BK. (Firman dan Rahayu, 2020). Dalam pelaksanaan pelaksanaan layanan BK online/daring membutuhkan dukungan perangkat-perangkat mobile seperti telepon pintar, tablet dan laptop yang dapat digunakan untuk mengakses informasi dimana saja dan kapan saja.

Dalam pelaksanaan layanan BK diperlukan evaluasi untuk melihat seberapa efektif proses pelaksanaan layanan BK yang telah ditetapkan kepada peserta didik. Secara konvensional evaluasi pelaksanaan layanan BK dilakukan dengan memberikan tes secara tertulis kepada peserta didik, dengan perangkat yang terdiri dari lembar soal dan lembar jawaban. Setelah itu guru harus memeriksa setiap lembar jawaban untuk mengetahui hasil evaluasi proses pelaksanaan layanan BK. Tentu saja hal ini sangat menyita waktu dan tenaga. Pada perkembangan teknologi yang sangat pesat dapat memberikan banyak kemudahan di berbagai bidang khususnya bidang pendidikan.

Pada masa pandemi sekarang sekolah diminta untuk melakukan pencegahan penyebaran Covid-19. Pemerintah melalui beberapa media, merekomendasikan untuk menghentikan sementara kegiatan- kegiatan yang berpotensi menimbulkan kerumunan massa. Untuk itu pelaksanaan layanan BK konvensional yang mengumpulkan banyak peserta didik dalam satu ruangan perlu ditinjau ulang pelaksanaannya. Pelaksanaan layanan Bimbingan dan Konseling (BK) harus dilaksanakan dengan skenario yang mampu meminimalisir kontak fisik antara 
peserta didik dengan peserta didik lain, ataupun antara peserta didik dengan guru. Menurut Milman (2015) penggunaan teknologi digital memungkinkan peserta didik dan guru berada di tempat yang berbeda selama proses pelaksanaan layanan BK.

Salah satu platform/media yang digunakan dalam pelaksanaan layanan bimbingan klasikal di SMP Negeri 8 Pamekasan adalah Google Form. Menurut Rahardja (2018) platform ini umumnya dimanfaatkan untuk mengisi data yang mudah dan efektif. Menambahkan fitur dari Google Form sangat mudah dan ramah diakses oleh pengguna dalam hal ini peserta didik. Begitu juga menurut Batubara (2016) Penggunaan Google Form sebagai alat penilaian proses pelaksanaan layanan BK juga mendukung program penghematan kertas sebagai wujud peduli lingkungan. Selain itu, tenaga dan waktu yang diperlukan guru untuk menyebarkan angket dan mengolah datanya lebih hemat dan mudah.

Menurut Aip Badrujaman (2011) Bimbingan dan konseling adalah seperangkat program pelayanan bantuan yang dilakukan melalui kegiatan perorangan dan kelompok untuk membantu peserta didik melaksanakan kehidupan sehari-hari secara mandiri dan berkembang secara optimal, serta membantu peserta didik mengatasi masalah yang dialaminya. Guru BK diharapkan dalam membimbing peserta didik, perlu untuk mengetahui permasalahanpermasalahan peserta didik secara pribadi, sosial, belajar, dan karir agar peserta didik bisa dibantu dan bisa menyelesaikan permasalahan dengan sendirinya.

Tohirin (2014) juga menegaskan bahwa bimbingan dan konseling merupakan proses bantuan yang diberikan oleh pembimbing (konselor) kepada individu (konseli) melalui pertemuan tatap muka atau hubungan timbal balik antara keduanya, supaya konseli mempunyai kemampuan atau kecakapan melihat dan menemukan masalahnya serta mempunyai kemampuan memecahkan masalahnya sendiri. Bimbingan dan Konseling (BK) merupakan pemberian bantuan kepada peserta didik dengan tujuan untuk mengembangkan potensi yang dimiliki peserta didik sehingga peserta didik bisa menerima diri, memahami diri, mengarahkan diri dan aktualisasi diri. Bimbingan bersifat preventif atau pencegahan sedangkan konseling bersifat kuratif atau perbaikan.

Bimbingan klasikal merupakan kegiatan layanan yang diberikan kepada sejumlah peserta didik/konseli dalam satu rombongan belajar dan dilaksanakan di kelas dalam bentuk tatap muka antara guru bimbingan dan konseling atau konselor dengan peserta didik/konseli. Bimbingan klasikal juga salah satu strategi layanan dasar serta layanan peminatan dan perencanaan individual pada komponen program bimbingan dan konseling. Bimbingan klasikal diberikan kepada semua peserta didik/konseli dan bersifat pengembangan, pencegahan, dan pemeliharaan.

Bimbingan klasikal adalah bimbingan yang berorientasi pada kelompok peserta didik dalam jumlah yang cukup besar antara 30-40 orang peserta didik. Bimbingan klasikal juga merupakan layanan dasar bagi peserta didik yang berjumlah antara 30-40 orang melalui kegiatan klasikal yang disajikan secara sistematis, terjadwal, bersifat preventif dan memberikan pemahaman diri dan pemahaman tentang orang lain yang berorientasi pada bidang pelaksanaan layanan BK, pribadi, sosial dan karir dengan tujuan menyediakan informasi yang akurat dan dapat membantu individu untuk merencanakan pengambilan keputusan dalam hidupnya kemudian mengembangkan potensinya secara optimal. Layanan bimbingan klasikal bukanlah suatu kegiatan mengajar atau menyampaikan materi pelajaran yang dirancang dalam kurikulum pendidikan sekolah, melainkan menyampaikan informasi yang dapat berpengaruh terhadap tercapainya perkembangan yang optimal seluruh aspek perkembangan dan tercapainya kemandirian peserta didik atau konseli.

Media merupakan bentuk-bentuk komunikasi baik tercetak maupun audiovisual serta peralatannya. Apapun batasan yang diberikan, ada persamaan diantara batasan tersebut yaitu bahwa media adalah segala sesuatu yang dapat digunakan untuk menyalurkan pesan dari pengirim ke penerima sehingga dapat merangsang pikiran, perasaan, perhatian dan minat serta perhatian peserta didik sedemikian rupa sehingga proses belajar terjadi. 
Sedangkan di dalam Media ada alat-alat grafis, photografis, atau elektronis untuk menangkap, memproses, dan menyusun kembali informasi visual atau verbal. Alat elektronik selama dalam proses belajar mengajar juga akan dapat memberikan hal yang sangat baik yaitu akan mempermudah interaksi antara peserta didik dengan peserta didik lainnya. Atau bahkan akan mempermudah interaksi antara peserta didik dengan guru atau pembimbing mereka. Para peserta didik akan membentuk organisasi belajar dalam lingkungan mereka dan hal inipun akan mereka bisa saling berbagi informasi atau pendapat mereka dalam mengikuti proses belajar tersebut. Berdasarkan uraian diatas, penelitian ini berfokus pada Efektifitas Penggunaan Google Form Selama BDR (Belajar Dari Rumah) dalam Pelaksanaan Kegiatan Layanan Bimbingan Klasikal di SMP Negeri 8 Pamekasan.

\section{METODE PENELITIAN}

Penelitian lapangan (field reseacrh) yang digunakan dalam metode penelitian ini bertujuan untuk mengetahui efektivitas penggunaan media google form sebagai platform yang digunakan dalam pelaksanaan layanan bimbingan klasikal selama Belajar Dari Rumah (BDR) di kelas IX-A s/d IX-F SMP Negeri 8 Pamekasan. Penelitian ini mengambil data dari hasil angket yang diberikan kepada peserta didik setelah pelaksanaan layanan bimbingan klasikal secara daring dilakukan. Dari data tersebut, kemudian dimanfaatkan dan dijabarkan secara deskriptif (sehingga penelitian ini dapat dikatakan sebagai penelitian kualitatif deskriptif).

Jumlah peserta didik dimasing-masing kelas IX yang menjadi anak asuh dalam Bimbingan dan Konseling berjumlah 27 orang kecuali kelas IX-F berjumlah 26 orang, sehingga jumlah keseluruhannya adalah 161 orang. Dan efektivitas penggunaan google form selama belajar dari rumah (BDR) dalam pelaksanaan layanan bimbingan klasikal ini dapat dilihat dari perasaan yang diterima peserta didik dalam pelaksanaan layanan bimbingan klasikal, penyampaian materi yang diberikan oleh Guru BK, menarik tidaknya layanan bimbingan klasikal yang diberikan/disampaikan, dan penting tidaknya materi yang disampaikan oleh Guru BK.

\section{HASIL DAN PEMBAHASAN}

Survey dilakukan terhadap peserta didik kelas IX-A s/d IX-F SMP Negeri 8 Pamekasan dengan jumlah keseluruhan 161 orang. Tujuannya adalah untuk memperoleh data keefektivan penggunaan media/platform google form dalam pelaksanaan layanan bimbingan klasikal yang dilaksanakan oleh Guru BK secara daring.

\section{Hasil}

Dari data yang diperoleh peneliti dari hasil survey dan dan jawaban yang diberikan oleh peserta didik, dapat diketahui bahwa: perasaan peserta didik dalam mengikuti kegiatan layanan bimbingan klasikal secara daring dengan menggunakan media google form yang menyatakan tidak menyenangkan rata-rata $6 \%$, yang menyatakan kurang menyenangkan ratarata $17 \%$, dan yang menyatakan menyenangkan rata-rata $77 \%$. Untuk jawaban peserta didik tentang topik/materi yang dibahas/disampaikan oleh Guru BK dalam kegiatan pelaksanaan layanan bimbingan klasikal secara daring dengan menggunakan media google form yang menyatakan tidak penting rata-rata $0 \%$, yang menyatakan kurang penting rata-rata $7 \%$, dan yang menyatakan penting rata-rata 93\%. Jawaban peserta didik tentang cara guru BK menyampaikan materi dalam pelaksanaan layanan bimbingan klasikal secara daring dengan menggunakan media google form yang menyatakan sulit dipahami rata-rata $7 \%$, yang menyatakan kurang dipahami rata-rata $8 \%$, dan yang menyatakan mudah dipahami rata-rata $85 \%$. Sedangkan jawaban peserta didik yang berkaitan dengan kegiatan yang diikuti dalam pelaksanaan layanan bimbingan klasikal secara daring dengan menggunakan media google form yang menyatakan tidak menarik untuk diikuti rata-rata $2 \%$, yang menyatakan kurang menarik untuk diikuti rata-rata $12 \%$, dan yang menyatakan menarik untuk diikuti rata-rata 83 $\%$. Dari uraian tersebut, maka dapat ditampilkan secara rinci pada tabel dan grafik berikut : 
Tabel 1. Jawaban peserta didik dalam pelaksanaan layanan bimbingan klasikal secara daring dengan menggunakan media google form

\begin{tabular}{|c|c|c|c|c|}
\hline No. & Pernyataan & Jawaban & $\begin{array}{c}\text { Jumla } \\
\mathbf{h}\end{array}$ & $\begin{array}{c}\text { Rata- } \\
\text { rata }\end{array}$ \\
\hline \multirow[t]{3}{*}{1.} & \multirow{3}{*}{$\begin{array}{l}\text { Perasaan pada waktu mengikuti } \\
\text { pelaksanaan layanan bimbingan } \\
\text { klasikal secara daring dengan } \\
\text { menggunakan media google form }\end{array}$} & Tidak menyenangkan & 9 & $6 \%$ \\
\hline & & Kurang menyenangkan & 28 & $17 \%$ \\
\hline & & Menyenangkan & 124 & $77 \%$ \\
\hline \multirow[t]{3}{*}{2.} & \multirow{3}{*}{$\begin{array}{l}\text { Topik/materi yang } \\
\text { dibahas/disampaikan } \\
\text { oleh Guru BK dalam pelaksanaan } \\
\text { layanan bimbingan klasikal secara } \\
\text { daring dengan menggunakan media } \\
\text { google form }\end{array}$} & Tidak penting & 0 & $0 \%$ \\
\hline & & Kurang penting & 11 & $7 \%$ \\
\hline & & Penting & 150 & $93 \%$ \\
\hline \multirow[t]{3}{*}{3.} & \multirow{3}{*}{$\begin{array}{l}\text { Cara guru BK menyampaikan materi } \\
\text { dalam pelaksanaan layanan bimbingan } \\
\text { klasikal secara daring dengan } \\
\text { menggunakan media google form }\end{array}$} & Sulit dipahami & 12 & $7 \%$ \\
\hline & & Kurang dipahami & 13 & $8 \%$ \\
\hline & & Mudah dipahami & 137 & $85 \%$ \\
\hline \multirow[t]{3}{*}{4.} & \multirow{3}{*}{$\begin{array}{l}\text { Kegiatan yang diikuti dalam } \\
\text { pelaksanaan layanan bimbingan } \\
\text { klasikal secara daring } \\
\text { dengan menggunakan media google } \\
\text { form }\end{array}$} & $\begin{array}{l}\text { Tidak menarik untuk } \\
\text { diikuti }\end{array}$ & 4 & $2 \%$ \\
\hline & & $\begin{array}{l}\text { Kurang menarik untuk } \\
\text { diikuti }\end{array}$ & 20 & $12 \%$ \\
\hline & & Menarik untuk diikuti & 135 & $83 \%$ \\
\hline
\end{tabular}

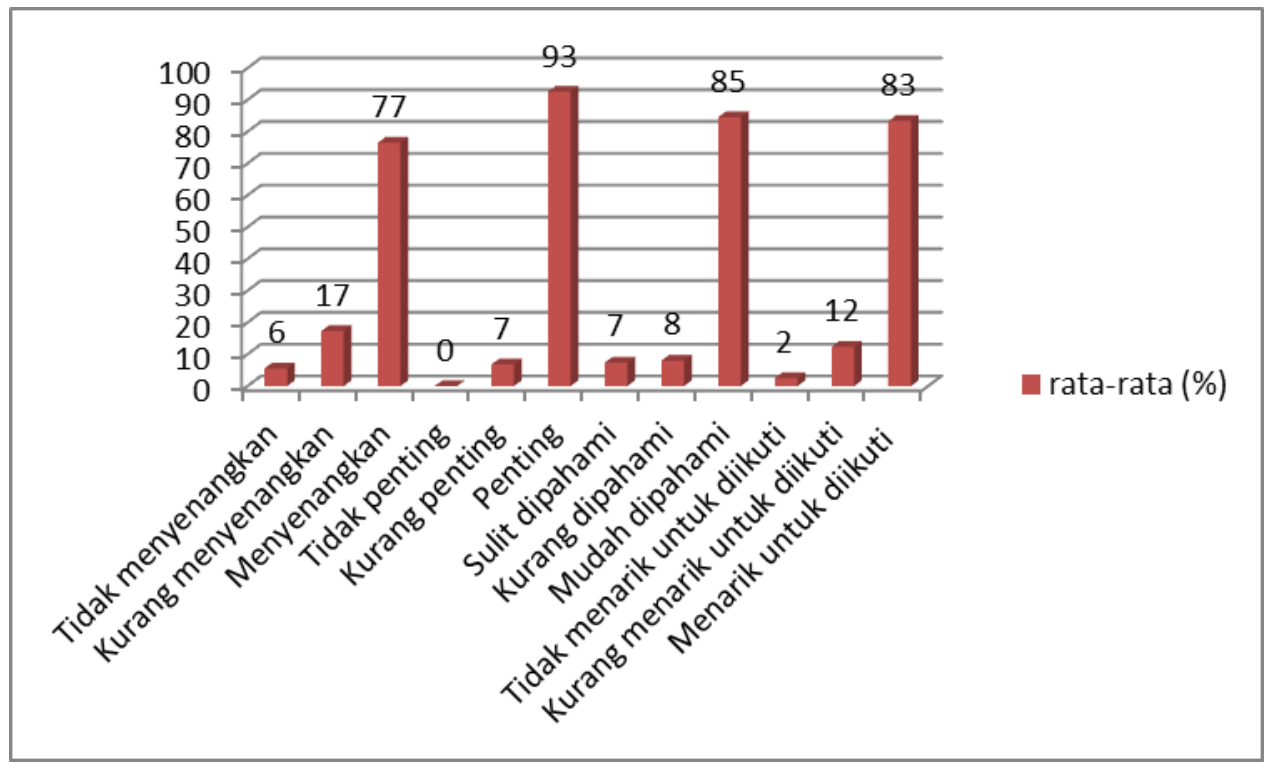

\section{Gambar1. Grafik jawaban peserta didik dalam pelaksanaan layanan bimbingan klasikal secara daring dengan menggunakan media google form}

\section{Pembahasan}

Pelaksanaan layanan bimbingan klasikal termasuk dalam salah satu komponen layanan dasar dalam Bimbingan dan Konseling, yang seharusnya dilakukan dalam kelas secara tatap muka dan terjadwal. Namun dalam masa pandemi covid-19 ini, maka pelaksanaannya dilakukan secara daring dengan instilah Belajar Dari Rumah (BDR). Proses pelaksanaan kegiatan layanan bimbingan klasikal secara daring yang dilakukan dengan menerapkan google form berlangsung aktif. Peserta didik menjadi lebih aktif dalam menyikapi materi yang disajikan dan cepat merespon pertanyaan dari guru. Hal ini dapat dilihat dari tingkat partisipasi peserta didik dari hasil respon di google form yang disampaikan melalui media 
whatsapp group. Dalam pelayanan ini, pemahaman peserta didik tentang materi layanan yang disampaikan benar-benar menunjukkan hasil yang positif.

Pelaksanaan layanan bimbingan klasikal walaupun dilakukan secara daring yang dilakukan dengan menggunakan google form dapat menyadarkan peserta didik akan pentingnya penyampaian informasi layanan dengan format bimbingan klasikal yang disampaikan oleh Guru BK. Setelah membaca dari materi layanan, menjawab pertanyaan, maupun mengerjakan latihan di google form yang disajikan oleh Guru BK, peserta didik dapat mengambil pemahaman yang positif. Pemahaman yang positif ini menjadi dasar bagi peserta didik dalam meningkatkan serta mengatasi permasalahan dan pengambilan sikap dalam kehidupan sehari-hari. Pelaksanaan layanan bimbingan klasikal secara daring dengan platform google form ini bukannya tidak menghadapi permasalahan/hambatan. Tentunya masih ada beberapa permasalahan di dalam pelaksanaannya, diantaranya : (1) peserta didik belum terbiasa mengikuti pelaksanaan layanan Bimbingan dan Konseling umumnya, dan bimbingan klasikal pada khususnya secara daring, (2) paketan internet yang dimiliki oleh peserta didik terbatas, bahkan tidak memiliki paketan sama sekali sehingga numpang pada teman/orang tua, dan (3) masih lemahnya sinyal provider di tempat tinggal peserta didik, sehingga untuk mengakses tugas dan mengikuti pelaksanaan layanan bimbingan klasikal tidak maksimal.

Pada awalnya pelaksanaan layanan bimbingan klasikal ini dikhawatirkan tidak efektif untuk dilaksanakan secara daring dan dengan menggunakan media google form. Namun kekhawatiran tersebut terpecahkan dengan hasil survey yang diperoleh dari responden/peserta didik kelas IX SMP Negeri 8 Pamekasan. Dari hasil survey yang dilakukan oleh penulis terhadap peserta didik kelas IX SMP Negeri 8 Pamekasan menunjukkan keefektivan pelaksanaan layanan bimbingan klasikal secara daring dengan menggunakan media google form. Hal tersebut ditunjukkan dari hasil pengumpulan dan pengolahan data/survey dari jawaban peserta didik yang menyatakan perasaan menyenangkan pada waktu mengikuti pelaksanaan layanan bimbingan klasikal secara daring dengan menggunakan media google form sebanyak 124 dari 161 peserta didik atau sebesar $77 \%$. Yang menyatakan pentingnya topik/materi yang dibahas/disampaikan oleh Guru BK dalam pelaksanaan layanan bimbingan klasikal secara daring dengan menggunakan media google form sebanyak 150 dari 161 peserta didik atau sebesar 93\%. Yang menyatakan bahwa cara guru BK menyampaikan materi dalam pelaksanaan layanan bimbingan klasikal secara daring dengan menggunakan media google form, mudah dipahami yakni sebanyak 137 dari 161 peserta didik atau $85 \%$, dan yang menyatakan kegiatan menarik untuk diikuti dalam pelaksanaan layanan bimbingan klasikal secara daring dengan menggunakan media google form sebanyak 135 dari 161 peserta didik atau $83 \%$. Sehingga pesersentase dari keempat pernyataan yang disampaikan oleh peserta didik tersebut kalau dirata-ratakan diperoleh data sebesar 84,5\%. Dari angka sebesar 84,5\% ini, dapat dikatakan bahwa pelaksanaan layanan bimbingan klasikal secara daring dengan menggunakan media google form dapat dikatakan efektif.

Penelitian ini sesuai dengan penelitian-penelitian yang dilakukan sebelumnya, antara lain; Wiwin Indah Lestari dan Eric Dwi Putra (2020), Fansuri Septiawan (2020), dan Pitoyo Budi Santoso (2019). Hasil penelitian Wiwin Indah Lestari dan Eric Dwi Putra (2020), efektivitas pembelajaran matematika menggunakan media pemberian tugas Google Form di masa pandemi Covid-19 terhadap hasil belajar siswa. Penelitian ini merupakan penelitian deskriptif dengan pendekatan kualitatif. Metode pengumpulan data menggunakan tes dan angket. Subyek pada penelitian ini adalah siswa kelas VII di SMPN 1 Tajinan Malang dengan jumlah 252 siswa. Hasil penelitian menunjukkan hasil belajar siswa yang tuntas mencapai $75.4 \%$ dan berada pada klasifikasi baik; respon siswa terhadap pemberian tugas Google Form berada pada kategori baik. Sehinga dari kedua kategori bisa diambil kesimpulan bahwa pembelajaran matematika dengan menggunakan media pemberian tugas Google Form dimasa pandemi Covid-19 dikatakan efektif. 
Fansuri Septiawan (2020), dalam pembelajaran diperlukan evaluasi untuk mengetahui hasil dari proses pembelajaran. Pada umumnya, evaluasi pembelajaran dilakukan secara tertulis menggunakan kertas dan membutuhkan waktu untuk memeriksanya. Pada masa pandemi COVID-19 sekarang, dunia pendidikan dalam hal ini sekolah dituntut untuk melakukan proses pembelajaran secara daring atau pembelajaran jarak jauh. Salah satu caranya dengan menggunakan Google Form. Dalam penelitian ini menggunakan penelitian kualitatif untuk mengetahui efektivitas penggunaan Google Form dalam pembelajaran daring pada masa pandemi COVID-19. Sebagai responden adalah siswa kelas XI TBSM SMK Negeri 1 Koba yang aktif mengikuti pembelajaran daring pada mata pelajaran pemeliharaan mesin sepeda motor. Dari hasil respon indikator angket didapatkan bahwa sebagian siswa menyatakan penggunaan Google Form sebagai media pembelajaran menunjukan respon positif, ini dapat dilihat dari rata-rata persentase sebesar 72,66\% dengan kategori baik. Dengan hasil ini Google Form dapat digunakan sebagai salah satu media pembelajaran pada masa pandemi COVID-19 sebagai alternatif pengganti pembelajaran tatap muka.

Pitoyo Budi Santoso (2019), efektivitas penggunaan media penilaian Google Form pada pelajaran Teknologi Informasi dan Komunikasi terhadap hasil belajar siswa Kelas IX SMP Negeri 9 Purworejo apabila dibandingkan dengan pembelajaran konvensional yang diberlakukan di sekolah tersebut. Metode penelitian yang digunakan dalam penelitian ini adalah metode penelitian quasi eksperimen dengan sampel penelitiannya adalah kelas IX A dan IX B SMP Negeri 9 Purworejo. Adapun desain penelitian yang digunakan adalah pretestposttest control group design. Uji beda dilakukan untuk mengukur perbedaan efektivitas media penilaian Google Form dan media pembelajaran konvensional berdasarkan kriteria hasil belajarnya. Berdasarkan hasil uji $\mathrm{t}$ dari nilai rata-rata hasil belajar diperoleh $\mathrm{t}$ hitung $>\mathrm{t}$ tabel $(2.870>1,669801$, serta nilai signifikansi $(\mathrm{P})$ adalah $0.006<\propto(0.05)$, dengan demikian Ho ditolak dan Ha diterima. Ini membuktikan bahwa media penilaian Google Form efektif untuk meningkatkan hasil belajar siswa kelas IX SMP Negeri 9 Purworejo.

\section{KESIMPULAN}

Dari akhir penulisan hasil penelitian ini dapat disimpulkan bahwa penggunaan media google form dalam pelaksanaan layanan bimbingan klasikal secara daring dikatakan efektif. Hal ini dapat dibuktikan dengan hasil survey yang dilakukan kepada peserta didik kelas IX SMP Negeri 8 Pamekasan yang menyatakan perasaan menyenangkan $77 \%$, topik yang dibahas dianggap penting $93 \%$, cara guru BK dalam menyampaikan materi mudah dipahami $85 \%$, dan kegiatan menarik untuk diikuti $83 \%$.

Dari pembahasan di atas, diharapkan pula (1) Guru BK sebagai faktor utama dan pertama dalam pelaksanaan layanan di sekolah, diharapkan selalu kreatif, aktif, inovatif, dan berdedikasi tinggi dalam melayani peserta didik di sekolah. (2) Guru BK selalu memiliki sikap dan prilaku yang baik dalam segala tindakan. (3) Guru BK selalu siap menangani segala masalah peserta didik, dan dapat membantu mengentaskan masalahnya dengan profesional. (4) Pelaksanaan layanan bimbingan klasikal diharapkan bukan satu-satunya yang dapat dijadikan kegiatan layanan Bimbingan dan Konseling untuk mengentaskan permasalahan. Pelaksanaan kegiatan layanan lainpun yang ada dalam program Bimbingan dan Konseling diharapkan dapat memberikan kontribusi positif untuk mengatasi berbagai permasalahan yang dihadapi peserta didik.

\section{DAFTAR PUSTAKA}

Badrujaman, Aip. (2011). Bimbingan Konseling, Jakarta Barat: Indeks.

Batubara, H. H. (2016). Penggunaan Google Form Sebagai Alat Penilaian Kinerja Dosen di Prodi PGMI UNISKA Muhammad Arsyad Al Banjari. Al-Bidayah: Jurnal Pendidikan Islam vol 8, nomor 1, Juni 2016; ISSN: 2085-0034. 
Septiawan, Fansuri. 2020. Efektivitas Penggunaan Google Form Dalam Pembelajaran Daring Pada Mata Pelajaran Pemeliharaan Mesin Sepeda Motor Di SMK Negeri 1 Koba, Jurnal Pendidikan Teknik Mesin, Volume 7 nomor 2 (November 2020)

Firman, \& Rahayu, S. (2020). Pembelajaran/pelaksanaan layanan BK Online di Tengah Pandemi Covid-19. Indonesian Journal of Educational Science (IJES), 2(2), 81-89.

Pitoyo Budi Santoso, (2019), Efekktivitas Penggunaan Media Penilaian Google Form Terhadap Hasil Belajar Pelajaran TIK, Prosiding Seminar Nasional : Kebijakan dan Pengembangan Pendidikan di Era Revolusi Industri 4.0., Shapir Hotel, 21 September 2019

Rahardja, U, dkk. (2018). Pemanfaatan Google Formulir sebagai Sistem Pendaftaran Anggota pada Website Asosiasi. Media Informatika Budidarma, Vol 2, no. 4, Oktober 2018.

Supardi. (2013). Sekolah Efektif, Konsep Dasar dan Praktiknya. Jakarta: Rajawali Pers.

Tohirin. (2014). Bimbingan dan Konseling, Jakarta: Rajawali Pers.

Wiwin Indah Lestari, dan Eric Dwi Putra . (2020). Efektivitas Pembelajaran Matematika Menggunakan Media Pemberian Tugas Google Form di Masa Pandemi Covid-19 terhadap Hasil Belajar Siswa, LAPLACE : Jurnal Pendidikan Matematika. 